
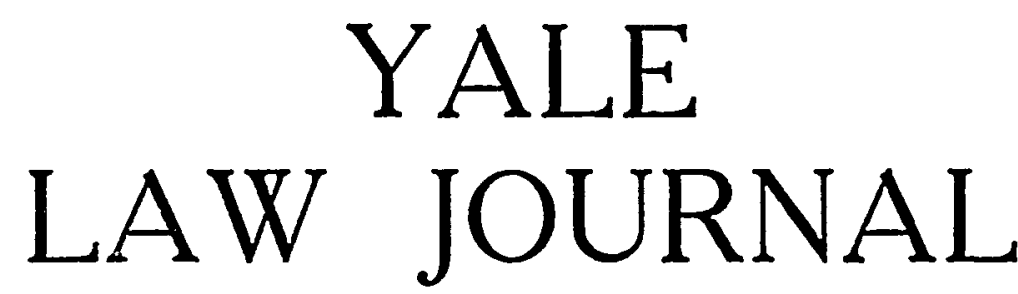

$\begin{array}{lll}\text { Vol. XXXV APRIL, } 1926 & \text { No. } 6\end{array}$

\title{
THE HISTORIC BACKGROUND OF CORPORATE
} LEGAL PERSONALITY

\section{JOHN DEWEY}

The survey which is undertaken in this paper points to the conclusion that for the purposes of law the conception of "person" is a legal conception; put roughly, "person" signifies what law makes it signify. If this conclusion had not been disputed, if it were even now generally accepted, if even when it is accepted in substance it were not complicated by the use of non-legal concepts employed to justify certain reasonings and conclusions, this paper would have no particular excuse for being written. For in that case, being a legal concept, it would be one to be discussed by lawyers rather than by a layman. Accordingly, the justification for a layman venturing into the field is precisely the fact that discussions and theories which have influenced legal practice have, with respect to the concept of "person," introduced and depended upon a mass of non-legal considerations: considerations popular, historical, political, moral, philosophical, metaphysical and, in connection with the latter, theological.' So many of these extra-

x Thus Geldart, an upholder of the doctrine of "real perconality", says: "The question is at bottom not one on which law and legal conceptions have the only or the final voice: it is one which law shares with other sciences, political science, ethics, psychology, and metaphysies". Geldart, Legal Personality (1911) 27 L. Quart. Rev. 90, at 94. On the next page he goes on to assert that "To say that all legal personality-whether of so-called natural or so-called juristic persons-is equally real because in fact the law gives it an existence, and equally artificial or fictitious because it is only the law which gives it an existence, is really to confonni personality with capacity". But he makes no attempt to show the difference between them, nor to state what harm would result in low if the two were "confounded". That "artificial" is not synonymous with "fictitious" is shown by IIachen, Corporate Personality (1910) 24 HARV. L. REv. 253, at 257: "That which is artificial is real, and not imaginary; an artificial 
neous influences have received a formulation in philosophy and from thence have proceeded to affect legal doctrines that a student of philosophy does not have to travel far beyond his own field to discuss them.

As a starting point we may take the following statement from Maitland, who has done so much to bring the question of the nature of corporate legal personality to the attention of English readers: "The corporation is (forgive this compound adjective) a right-and-duty-bearing unit. Not all the legal propositions that are true of a man will be true of a corporation. For example, it can neither marry nor be given in marriage; but in a vast number of cases you can make a legal statement about $x$ and $y$ which will hold good whether these symbols stand for two men or for two corporations, or for a corporation and a man." : In saying that "person" might legally mean whatever the law makes it mean, I am trying to say that "person" might be used simply as a synonym for a right-and-duty-bearing unit. Any such unit would be a person; such a statement would be truistic, tautological. Hence it would convey no implications, except that the unit has those rights and duties which the courts find it to have. What "person" signifies in popular speech, or in psychology, or in philosophy or morals, would be as irrelevant, to employ an exaggerated simile, as it would be to argue that because a wine is called "dry," it has the properties of dry solids; or that, because it does not have those properties, wine cannot possibly be "dry." Obviously, "dry" as applied to a particular wine has the kind of meaning, and only the kind of meaning, which it has when applied to the class of beverages in general. Why should not the same sort of thing hold of the use of "person" in law?

To take an illustration nearer to our theme, when the common law refused to recognize any paternity for an illegitimate son, and said he was filius nullius, it was not understood to deny the fact of physiological begetting; it was asserting that such a one did not possess the specific rights which belong to one who was filius, implying wedlock as a legal institution. That filius sig-

lake is not an imaginary lake". Again he says: "A corporation cannot be at the same time 'created by the state' and fictitious. If a corporation is 'created' it is real, and therefore cannot be a purely fictitious body having no existence except in the legal imagination". Much the same points were made by Pollock. He says, that "artificial" means "in accordance with rules of art, lawyer-like, juridical", and that "fiction" should bo derived from fingere in the sense of creating or making, not feigning. Theory of Corporations in Common Law (1911) 27 L. QUART. REv. 210, 220, reprinted in Essays in the Law (1922) 153. Geldart's introduction of the word "only" in the phrase "because it is only the law" is like saying of a locomotive that "only" man gives it existence.

23 Maitland, Collected Papers (1911) 307. Throughout this paper, "corporate" is used in its broad sense, of which a business corporation is but $a$ species and which includes bodies not technically incorporated. 
nifies a certain kind of heir, one implying a prior union of man and woman authorized by law, is an example of a term signifying what the system of rights and duties makes it signify. To take another illustration still nearer our topic, suppose that a number of married women, who, under common law suffered from disability to contract, had formed a corporation. It may be doubted whether even the most ardent disciple of the theory that the association is nothing but the sum of its individual members would infer that the corporation could not contract-although of course it might have been denied that the women could form a corporation. Admitting, however, the existence of the corporation, the right to contract would have been limited to the new relationship; because of it, the members of the corporation vould possess a right sui generis. In a similar way, even if it were true, as it is not, that "natural person" is a wholly unambiguous: term, to term a "natural" person a person in the legal sense is to confer upon it a new, additive and distinctive meaning; a meaning sui generis, as far as "natural person" is concerned.

If in justification of a particular decision in some particular and difficult controversy, a court supports itself by appealing to some prior properties of the antecedent non-legal "natural person," the appeal may help out the particular decision; but it either involves dependence upon non-legal theory, or else it extends the legal concept of "natural person," or it does both. This statement cuts in two ways. On the one hand, it indicates that much of the difficulty attending the recent discussion of the real personality of corporate bodies is due to going outside the strictly legal sphere, until legal issues have got complicated with other theories, and with former states of seientific knowledge; and on the other hand it suggests that law, at eritical times and in dealing with critical issues, has found it difficult to grow in any other way than by taking over contemporary non-jural concentions and doctrines. Just as the law has grown by taking unto itself practices of antecedent non-legal status, so it has grown by taling unto itself from psychology or philosophy or what not extraneous dogmas and ideas. But just as continued growth with respect to the former requires that law be again changed with great changes in further practices, just as, to be specific, the adoption of the law-merchant will not provide law adequate for the complex industrial relations of today, so it is even more marliedly true that old non-legal doctrines which once served to advance rules of law may be obstructive today. We often go on discus:ing problems in terms of old ideas when the solution of the problem depends upon getting rid of the old ideas, and putting in their place concepts more in accord with the present state of ideas and knowledge. The root difficulty in present controversies about "natural" and associated bodies may be that while we 
oppose one to the other, or try to find some combining union of the two, what we really need to do is to overhaul the doctrine of personality which underlies both of them.

The purpose of the article is, in other words, to point out some of the non-legal factors which have found their way into the discussion of the personality of so-called natural and artificial persons, and to indicate the original conditions which gave these extraneous factors their efficacy. The postulate, which has been a controlling principle although usually made unconsciously, leading to the merging of popular and philosophical notions of the person with the legal notion, is the conception that before anything can be a jural person it must intrinsically possess certain properties, the existence of which is necessary to constitute anything a person. If the conception as to the nature of these inherent and essential attributes had remained constant perhaps no harm would have resulted from shoving such a notion under the legal idea; the legal doctrine would at least have remained as constant as that of the nature of the seat of personality. But the history of western culture shows a chameleon-like change in the latter notion; this change has never, moreover, effected complete replacement of an earlier by a later idea. Almost all concepts have persisted side by side in a confused intermixture. Hence their influence upon legal doctrine has necessarily been to generate confusion and conflict.

We may illustrate by recourse to Maitland. The quotation above made, taken apart from its context, would appear to use "person" in a neutral sense, as signifying simply a right-and-duty-bearing unit. But actually his discussion depends upon an assumption that there are properties which any unit must antecedently and inherently have in order to be a right-and-duty-bearing unit. They are stated in his summary of Gierke's position, although the statement is found in another book. A "universitas [or corporate body] . . . is a living organism and a real person, with body and members and a will of its own. Itself can will, itself can act . . . it is a group-person, and its will is a group-will." 3 I do not intend to imply that Maitland or Gierke ever adopted all the extreme analogies with an "organism" into his corporate unit, but a "will" he certainly thinks is presupposed for being a legal person. In short, some generic or philosophic concept of personality, that is, some concept expressing the intrinsic character of personality ueberhaupt, is implied. And here is room for questions of general theory and the writing of many books to show that legal units do or do not have the properties required by the concept, and that "will" means this or that or the other thing.

3 Gierke, Political Theories of the Middle Age (1902) xxvi (translated and prefaced by Maitland). 
Another example will make the implication more explicit. Michoud says: "For legal science, the notion of person is and should remain a purely juridical notion. The word signifies simply a subject of rights-duties, [sujet de droit] a being capable of having the subjective rights properly belonging to him." : This sounds very much like saying "person" means what the law makes it mean in real distribution of rights and duties-although the word "subjective" prefixed to rights might make wary one who was acquainted with philosophical literature. But Michoud at once goes on to say: "To know if certain beings correspond to this definition, it is not necessary to ask if these beings constitute persons in the philosophical sense of the word. It is enough to ask if they are of such a nature that subjective rights may be attributed to them". Considerations extraneous to law are here nominally excluded, but they are actually taken in under the guise of the necessity of inquiring into the nature of the subjects, independently of and prior to the attribution of duty-rights. The word "subject" might have been used in legal theory simply as a descriptive term, denoting whatever is a right-and-duty-bearing unit. But in fact it has not been so used; it has been thought necessary-especially in German theory which has spread-first to define what makes anything properly a subject, as a piccondition of having right-duties, and the German theory of "subjectivity" is itself a theme for volumes. This something-or-other must then be the same in whatever has rights and duties. The readiest starting point is a singular man; hence there is imposed the necessity of finding some nature or essence which belongs both to men in the singular and to corporate bodies. If one denies that he can find such a common essence he holds that "person" as applied to corporate bodies denotes only a fiction. But if he denies the fictitious character of a corporate entity, then some personality identical in essence, or with respect to "subjeetivity," must be discovered for all right-and-duty-bearing units, from the singular man on one side (including infants, born and unborn, insane, etc.) to the state on the other, together with all kinds of intervening corporate bodies such as "foundations," "associations" and corporations in the economic sense. Clearly, this is not an easy task; it is so difficult of accomplishment that it accounts in the main for the voluminous continental literature concerning juridical personality, or as French writers generally say, "Les Personnes Morales." But this is not the whole story.

\footnotetext{
4 Michoud, La Notion de Personnalité Morale (1899) 11 Revene nu Drolt Public, 1 , at 8.

5 The first of these terms have their doctrinal signifieance in Continental rather than in Anglo-American law, the institution of trusteeship in the latter covering much of the ground. The theory of "azsociations" derived much of its point in the past from controversies regarding the legal status of religious congregations, to which is now added that of trade-unions.
} 
"Subject" and "subjectivity" occupy in modern German philosophy (which directly and through writings on jurisprudence has had an enormous influence in Latin countries and considerable in England) the place taken in ancient metaphysics by "substance" and also by "subject" of a judgment in a logical sense. Thus the search for the common essence has been so affected by philosophical theories regarding "the subject" that it is extremely difficult to get the full force of the various solutions proffered for the problem without knowledge of German technical philosophy, that of Kant in particular.

- It may be objected, however, that aside from all such philosophical theories regarding an "essence" or "nature" and regarding a "subject," it is only common sense that whatever is a right-andduty-bearing unit should have a character of its own in virtue of which it may possess rights-obligations; there must be a subject to which these legal relations belong or in which they inhere or to which, at all events, they are imputed. Otherwise why are not molecules, or trees or tables just as fit candidates for legal attributes as singular men and corporate bodies? The objection seems serious. But consider first an argument ad hominem, or rather ad hoc. There is no general agreement regarding the nature in se of the jural subject; courts and legislators do their work without such agreement, sometimes without any conception or theory at all regarding its nature; it can be shown that recourse to some theory has more than once operated to hinder rather than facilitate the adjudication of a special question of right or obligation. Moreover, English jurisprudence has accomplished by means of "trust" much that Continental law has accomplished by other means. One might then be justified in adopting a position of legal agnosticism, holding that even if there be such an ulterior subject per se, it is no concern of law, since courts can do their work without respect to its nature, much less having to settle it.

It would, however, be retorted that such an attitude does not become jurisprudence, that some theory is implied in the procedure of courts, and that the business of the theory of law is to make explicit what is implied, particularly as false theories have done practical harm, while the lack of intelligent consensus of ideas has encouraged judicial empiricism, and thereby wrought confusion, conflict and uncertainty in specific decisions. This retort brings us to a deeper level. There are two radically different types of definitions ; first, the type inherited from Greek logic reflecting a definite metaphysical conception regarding the nature of things. This definition proceeds in terms of an essential and universal inhering nature. There is another mode of definition which proceeds in terms of consequences. In brief, for the latter a thing is-is defined as-what it does, "what-itdoes" being stated in terms of specific effects extrinsically 
wrought in other things. This logical method was first stated by Charles S. Peirce as the pragmatistic rule: "Consider what effects, which might conceivably have practical bearings, we conceive the object of our conception to have. Then, our conception of these effects is the whole of our conception of the object".. The mode of definition, however, has no inherent dependence upon pragmatism as a philosophy. It has been stated and adopted on the basis of analysis of mathematics and physics by writers who would be horrified to be called pragmatists. Thus stated, it is the principle known as "extensive abstraction", and assumes this form: ". . . what really matters to science is not the inner nature of objects but their mutual relations, and that any set of teims with the right mutual relations will answer "all scientific purposes as well as any other set with the same sort of relations"."

From this point of view, the right-and-duty-bearing unit, or subject, signifies whatever has consequences of a specified kind. The reason that molecules or trees are not juridical "subjects" is then clear; they do not display the specified consequences. The definition of a legal subject is thus a legitimate, and quite conceivably a practically important matter. But it is $a$ matter of analysis of facts, not of search for an inhering essence. The facts in question are whatever specific consequences flow from being right-and-duty-bearing units. This analysis is a matter to be conducted by one competent in law, and not by the layman. But even a layman can point out the field within which the search falls. The consequences must be social in character, and they must be such social consequences as are controlled and modified by being the bearing of rights and obligations, privileges and immunities. Molecules and trees certainly have social consequences; but these consequences are what they are irrespective of having rights and duties. Molecules and trees would continue to behave exactly as they do whether or not rights and duties were ascribed to them; their consequences would be what they are anyway. But there are some things, bodies singular and corporate, which clearly act differently, or have different consequences, depending upon whether or not they possess rights and duties, and according to what specific rights they possess and what obligations are placed upon them. If the logical principle

- Chance, Love and Logic (1923) 45, edited by Miorris R. Cohen. The original article was printed in the Popular Science Monthly for January, 1878.

I Broad, Scientific Thought (1923) 39. The idea and the name are talien, however, by hin from $A$. N. Whitehead. This is a more general statement than Peirce's, because it applies to mathematical concepts, such as "point", whose "consequences" are not physical effects. In concrete matters, the "mutual relations" which count are, however, of the nature of effects. 
be granted, it is a factual matter what bodies have the specifiable consequences and what these consequences are; but it becomes a verbal matter whether we call them all "persons", or" whether we call some of them persons and not others-or whether we abandon the use of the word entirely..$^{8}$

The general statement as to the type of definition demanded may be made more specific by recurrence to Michoud. He finds what he is in search of primarily in "interests". Now while he had asserted the necessity of determining whether the beings who are "persons" "are of such a nature that subjective rights may be attributed to them", his conclusion that "interests" are primary shifts the logical ground. For "interests", whatever else they are or are not, fall within the region of consequences, not of "beings". It is true that he adds "will" as a secondary defining element. Certain interests are protected by the rights and duties of charitable foundations; but these interests are those of recipients, who have no rights in the matter. Beings possessed of will, administrators, are necessary as the organs of the interest. His secondary mark or criterion may be said then to introduce an inherent factor, that of "will". But our former logical question recurs: Is "will" conceived or defined in terms of something intrinsic, or in terms of specifiable consequences? If the former, then we are at once involved in all the controversies regarding the nature of will found in psychology and philosophy:there is no question upon which there is less consensus than upon the nature of will. ${ }^{9}$ If the man of "common-sense" retorts, "Away with these metaphysical subtleties; everybody knows well

8 English statutory law comes, in some respects, close to doing the latter by its very generalization of the term "person". In (1833) $3 \& 4 \mathrm{Wm}$. IV, c. 74, it is said: "The Word 'Person' shall extend to a Body Politic, Corporate, or Collegiate, as well as an Individual". In the Interpretation Act of 1889,52 \& 53 Vict. c. 63 , sec. 19 , it is stated: "In this Act and in every Act passed after the commencement of this Act the expression 'person' shall, unless the contrary intention appears, include any body of persons corporate or unincorporate".

I owe the reference to Maitland, op. cit. supra note 2, at 401. He explains the the inclusion of "incorporate bodies" is probably due to the desire to include some organs of local government, such as boards of health, under their relevant legal rules. He adds: "It is not inconcoivable that the above cited section of the Act of 1889 may do some work hereafter; but I have not heard of its having done any work as yot". This statement indicates what is meant by the assertion that a generalization of the term "person" may be equivalent to an abandonment of the term, the work being done by specific statutes and judicial decisions bearing upon specific matters.

9 One illustration, trivial in itself, but significant in what it stands for, is the necessity the adherents of the "will" theory find themselves under, of distinguishing volitions from volonté. Volitions may proceed from the singular members of an association; volonté belongs to the association as such. Saleilles, De la Personalité Juridique (1910) 565. 
enough the difference between a being with will and one without one," his retort may be true for most cases; but it involves more than "common-sense" is usually willing to acknowledge: namely, that "will" denotes certain empirically detectable and specifiable consequences, and not a force or entity, psychological or metaphysical. In other words, we determine the absence or presence of "intent", and the kind of "intent", by discrimination among concrete consequences, precisely as we determine "neglect", which by definition is not a peculiar kind of inhering ageney. Neglect may, of course, be made into a positive and intrinsic force or agency by hypostatization, but this is parallel to the procedure of school-teachers who make a positive existential entity out of "inattention". If we recur to the logical method of conception by "extensive abstraction", "will", like "interests", denotes a function, not an intrinsic force or structure. ${ }^{10}$

\section{II}

The foregoing section does not attempt to define what it is to be a "person" in the sense of a right-and-duty-bearing unit. Its purpose is to show the logical method by which such a definition should be arrived at; and, secondly, to show that the question has been enormously complicated by the employment of a wrong logical method, and by the introduction of irrelevant conceptions, imported into legal discussion (and often into legal practice) from

${ }^{10}$ It would require an article longer than this one merely to list and describe various theories about will which, as held at one time or anather, have influenced legal doctrines. One reference must suffice. Professor Pound has repeatedly shown how the conception of "will" was central in the Roman law idea of legal transactions and how it affected the nineteenth century theory of contracts and related subjects. The entire postKantian German concept of real personality is affected by the latter's theory of will. 'Practically, the movement fell in with another, quite different in character, which made "liberty" of will the central thing in order to find a universal basis of political liberty-as with Roussean. Subsequently, the German and French ideas flowed together, and the conflux: was affected by the notion of economic liberty, which readily rationalized itself by getting under the cover of the reigning theory of will. That the idea assisted in promoting movements which vere socially useful there can be no doubt. To give one instance, Henderson has suggested its utility in liberalizing the treatment of foreign corporations, which upon the "concession" theory find the going very difficult. See Henderson, Position of Foreign Corporations in American Constitutional Law (1918) 5.

My colleague, Professor H. W. Schneider, has called my attention to the important influence exercised upon theories of the "real" legal personality of corporate groups by the traditional association of the ideas of "ageney", "responsibility" and "guilt" with will. I have omitted diseussion of this point because its importance would demand an entire paper, at least, for adequate treatment. I would only suggest that the grouping of these ideas together is at present a matter of historic interest, but is unnecessary from the standpoint of contemporary thought. 
uncritical popular beliefs, from psychology, and from a metaphysics ultimately derived from theology. It is not intended, however, to imply that these extraneous considerations have not been historically significant, nor that the causes of their emergence into law is not of importance for legal history. The reverse is the case. To the student, and not merely the historical student, of human culture, they afford a fascinating, if intricate, field of inquiry; and the history and present status of legal institutions is involved in this study of human culture. The sources, career and effects of the conceptions of "intent" and of "malicious" intent would alone lay bare an instructive cross-section of the whole history of religion, morals and psychology. Of more direct significance for our special theme is the fact that the underlying controversies and their introduction into legal theory and actual legal relations, express struggles and movements of immense social import, economic and political. Such a formal or logical analysis as we have been engaged in is in fact but preliminary. What is back of these factors which are logically extraneous? What vital issues have led to their getting so thoroughly mixed up with questions of legal definition? To answer this question is to engage in a survey of the conflict of church and empire in the middle ages; the conflict of rising national states with the medieval Roman empire; the struggle between dynastic and popular representative forms of government; the conflict between feudnl institutions, ecclesiastic and agrarian, and the economic needs produced by the industrial revolution and the development of national territorial states; the conflict of the "proletariat" with the employing and capitalist class; the struggle between nationalism and internationalism, or trans-national relations, to mention only a few outstanding movements. ${ }^{11}$ These conflicts are primarily political and economic in nature. But there is not one of them which has not left its profound impress upon the law, including

11 Since the last-named topic will not concern us further, one illustration may be mentioned. One potent recent motive for the insistence upon the real "personality" of social groups, or corporate bodies, independent of tho state, is opposition to the claim that the state is the sole or even supreme Person. The latter notion reflects the increase of importance of the national territorial state. Opposition from the side we are alluding to, is due to the fact that the doctrine of the ultimate personality of these states finds fitting expression in wars. Moreover, these wars confer upon the states too unrestricted power over their citizens, and also unfavorably affect the complex economic interdependences wrought by modern methods of industry and commerce. In an article written before the war, Lindsay rightly cites Norman Angell as a factor "in the newest political gospel" which "makes open and declared war against the doctrine that the State is a personality". This attack is inspired "not by a belief in the isolation of individuals, but by a perception that the co-operation of individuals and their common dependence on one another extends beyond the bounds of the State." Lindsay, The State in Recent Political Theory (1914) 1 POLITICAL QUARTERLY, 128, at 130 and 132. 
particularly the doctrines of the nature and seat of juridical personality. Discussions and concepts may have been in form intellectual, using a full arsenal of dialectical weapons; they have been in fact, where they have any importance, "rationalizations" of the positions and claims of some party to a struggle. It is this faet which gives such extraordinary interest to the history of doetrines of juridical personality. Add to this fact that the intellectual and scientific history of western Europe is reflected in the changing fortunes of the meanings of "person" and "personality", a history which has both affected and been affected by the social struggles, and the interest and complexity of the doctrines about juridical personality are sufficiently obvious.

For example, the "fiction" theory of the personality of corporate bodies, or universitates, was promulgated if not originated, by Pope Innocent IV (1243-1254. St. Thomas Aquinas died in 1274). It is hardly a coincidence that Pope Innocent was one of the strongest upholders of the supremacy of the spiritual orer the temporal power, and that he was Pope immediately after the time of the greatest political power of the Papal Empire. ${ }^{22}$ In outward form the doctrine that corporate bodies are pcrionas fictae was directed at ecclesiastic bodies. The doctrine was stated as the reason why an ecelesiatic collegizm or univ'crisitas, or capitulum could not be excommunicated, or be guilty of a delict. For nomina sunt juris et non personarm; they have neither at body nor a will. A chapter was but a name and an incorporeal res. Other canonists declared that corporate bodies could not be punished or excommunicated because they had neither a soul nor a body, and carried their nominalism so far as to say that they had being only in abstracto, like "man" in respect to men. The doctrine did not imply, however, that excommunication was of no effect; on the contrary, it signified that, in order that a decree of punishment or excommunication should not lack effect, it was to be applied to all, omnes singulos. Even if Pope Innocent had not included populus et gens et hujus modi along with ecclesiastical groups (we cannot call them bodies on his theory), we may be sure that what applied to religious organizations applied $\alpha$ fortior $i$ to civil. A chapter or a populus regarded as an entity would not suffer especially from excommunication; it was wholly different when the ban fell upon "omnes singu!os". ${ }^{13}$ The intellectual

I2 Of a not far remote predecessor, it is said that "The fully rounded ecelesiastic theory, at the climax of actual ecelesiastic power, is to be found in the writings of Pope Innocent III (pontificate 1196-1216)." Dunning, Political Theories, Ancicnt and Mcdiacral (1902) 162, 163.

Is I have relied upon Gierke for the references $(3 \mathrm{Des}$ deutches Gonos3crlschaftrecht, 279-285.) Gierke says that Pope Innocent IV "was the jather of the dogma of the purely fictitious and intellectual character of juridical persons which still rules". Even if this statement were not literally correct the reference would be of great importance because of the curroncy 
factor in the doctrine takes us to the fact that being a "person" was denied to these groups because of the dominant conception of person. The current idea is expressed in the definition of St. Thomas Aquinas, vera persona est rei rationabilis individuce substantia. In this definition every one of the three last words has a technical meaning going back to the metaphysical discussions of Aristotle; the problem of the nature of the "individual" being, indeed, for the middle age philosophers, even more of a problem than that of "substance", which had been decided once for all by Aristotle. ${ }^{14}$ The consequences of including "rational individuated substance" in the conception of "person" endured long after the metaphysics and theology which gave it birth were obscured if not forgotten; and they account for much of the difficulty in even recent discussion in attributing "person" to corporate as well as to single units.

The "concession" theory of juridical persons, while often confused with the "fiction" theory, had a different origin, and testifies to quite a different situation of conflict of interests. It is essentially a product of the rise of the national state, with its centralizing tendencies and its objection to imperia in imperio at a time when religious congregations and organizations of feudal origin (communes and guilds) were rivals of the claim of the national state to complete sovereignty. The shortest cut to making good its claims was to treat all minor organizations as "conjurations" and conspiracies, except as they derived all their powers from an express grant of a supreme power, the State. Certain classes were as much interested in magnifying the government and regulation by statute law as Pope Innocent III was in magnifying the authority and power of the Papacy. The choice of the word "concession" was probably influenced by Roman law. ${ }^{15}$

Maitland gave to the discussion and to Gierke, and because of the influence of Maitland upon Laski, one of the chief modern propounders of the doctrine that organized groups have personality independent of, and in many cases prior to, state action.

14 We are far away from the Latin persona which when applied to a man in the concrete hardly meant more than a separate physical body. The change in meaning was undoubtedly of theological origin, the term "persona" having been applied by the fathers (first I believe by Tertullian) to the hyspostases of the Trinity.

Is Gaius, Digest, III, 4, 1. In all events, it is suggestive that the statements of Gaius were made at a time (161 A. D.) when the Empire was in full centralizing course. It should be noted, however, that Gaius is not referring explicitly to anything he calls persons. His point is that being a universitas or collegium is something dependent upon statutes, sensatus consulta and imperial constitutions. It is interesting, moreover, to note in connection with the efforts to bring Roman ideas into the whole controversy that Maitland expressly says that "The admission must be made that there is no text which directly calls the universitas a porsona, and 
In lieu of an extended discussion of the practical motivation of the basic ideas of the concession theory, I shall give one quotation. "In its various forms of ecclesiastical bodies and foundations, gilds, municipalities, trading companies, or business organizations, the corporation has always presented the same problem of how to check the tendency of group action to undermine the liberty of the individual or to rival the political power of the state. The somewhat vague theory of the later Middle Ages that communal organization not sanctioned by preseription or royal license was illegal was at least from the fifteenth century on supplemented by the technical doctrine, developed under canonist influences, that there is no capacity to act as a body corporate without positive authorization. To grant this authority has remained in England an attribute of the royal prerogative. . . . It is hardly possible to overestimate the theory that corporate existence depends on positive sanction as a factor in public and legislative policy. It is natural that the charter or incorporation law should be made the vehicle of restraints or regulations which might not be readily imposed upon natural persons acting on their own initiative, and the course of legislative history bears this out." 10

It is clear that there is nothing essentially in common between the fiction and concession theories, although they both aimed toward the same general consequence, as far as limitation of power of corporate bodies is concerned. The fiction theory is ultimately a philosophical theory that the corporate body is but a name, a thing of the intellect; the concession theory may be indifferent as to the question of the reality of a corporate bady; what it must insist upon is that its legal power is derived. In some respects, the concession theory is the more farorable to expanded power of corporations; a charter of broad powers might be granted and the courts might construe its terms liberally. Its conceded assimilation to the singular person, even when a

still less any that calls it persona ficta." Gierke (with preface by Maitland), supra note 3 , at xviii.

10 Freund, Standards of American Legislation (1917) 39. The guotation continues by indicating the restraints imposed on banking and insurance corporations, railways and express companies. Historically, the restrictive attitude towards at least business corporations finds its explanation and justification in the fact that they were few and exceptional, being usually huge trading companies, actually and often nominally, monopolics, whose "rights" were privileges and immunities. As so often happened, words, with associated ideas and temper of mind, persisted after corporations had become commonplace and, indeed, the usual means of carrying on busines: Henderson, in the work already referred to, has shown the efrect of poscession of extraordinary privileges by early corporations in creating fear of them and the extent to which this fear influenced court decisions, as for example, that in the case of The Banle of the C"nitcd States i. Devcan, op. cit. supra note 10 , at $19,55,56$. 
corporation is called "artificial", might even enlarge its rights, privileges and immunities. In an "individualistic" period-that is, an era chiefly concerned with rights of private property and contract-it is pretty sure to do so. Consider, for example, the court decisions that a business corporation is a "person" in the sense covered by the Fourteenth Amendment, and the effects of this decision. On the other hand, the fiction theory that a corporation having no soul cannot be guilty of delict gives a corporation considerable room in which to manoeuvre. Thus we cannot say, without qualification in respecting time and conditions, that either theory works out in the direction of limitation of corporate power. ${ }^{17}$

In spite of their historical and logical divergence, the two theories flowed together. Their conflux and its result is exhibited in many decisions of American judges. The practical key to the union, in which the feigned theory on the whole got the better of the concession theory, resides in the allusion just made to an "individualistic" age. When it is difficult to lay hands on the single persons who are said to be the only "real" persons, it is very convenient to do business as a fiction. With respect to its property, the fictitious entity has a clear title as an entity; with respect to its liabilities and burdens outside of property and contract, its position is not so clear; its fictitious character may be cited to relieve it of some obligations usually regarded as moral, and yet legally enforceable as regards single per'sons. Pope Innocent IV was under no such difficulty. Excommunication could reach down to every part of the aggregate whole; it is not so easy to reach the fluctuating "real" persons who form that "merely collective aggregate", the share-holders in a joint-stock company, especially if they are "widows and orphans". To a considerable extent, the corporation has "had it both ways" when the corporation was regarded as nothing but a name for an aggregate or collection of real persons. Adequately to develop this fact and the reasons for it would require an excursion into the change which took place in the eighteenth and nineteenth centuries in the concept of the "singular person", now become the full-fledged individual in his own right. The ex-

15 Imaginary beings or fictions may not only gain privileges because of the absence of souls, but because of the unlimited elasticity of fictions. As Machen says, "If the corporate personality is imaginary, there is no limit to the characteristics and capacities which may be attributed to that personality. . . . If you can imagine a corporate entity is a person, you can also imagine that this person has a mind". Machen, op. cit. supro note 1 , at 347,348 . The "fiction theory", if it had been separated wholly from the "concession theory", might have lent itself to liberalizing the theory of foreign corporations. Difficulties regarding "residence" and "migration" might easily have been got over; for imaginary creatures are notoriously nimble. 
cursion cannot be undertaken. Suffice it to say that the single person, as the "real person", is no longer either a physical body or a rational substance. These two meanings persist, but they are covered up with vestments derived from the theory of natural rights inhering in individual persons as such. The contrast of "natural" and "artificial" persons got its point from the fact that "natural" connoted possession of inherent and inviolable rights. The dialectic of the courts, under the pressure of social facts, was equal to declaring that corporations, while artificial and fictitious, nevertheless had all the natural rights of an individual person, since after all they were legal persons.

Perhaps a reader may infer that the foregroing amounts to a plea for the "real" personality of corporate bodies. Recurrence to the introductory remarks should, however, dissipate this impression. As far as the historical survey implies a plea for anything, it is a plea for disengaging specific issues and disputes which arise from entanglement with any concept of personality which is other than a restatement that such and such rights and duties, benefits and burdens, accrue and are to be maintained and distributed in such and such ways, and in such and such situations.

\section{III}

The fact of the case is that there is no clear-cut line, logical oi practical, through the different theories which have been advanced and which are still advanced in behalf of the "real" personality of either "natural" or associated persons. Each theory has been used to serve the same ends, and each has been used to serve opposing ends. The doctrine of the personality of the state has been advanced to place the state above legal responsibility on the ground that such a person has no superior person-save God-to whom to answer; and in behalf of a doctrine of the responsibility of the state and its officers to law, since to be a person is to have legal powers and duties. The personality of the state has been opposed to both the personality of "natural" singular persons and to the personality of groups. In the latter connection it has been employed both to make the state the supreme and culminating personality in a hierarchy, to malse it but primus inter paros, and to reduce it to merely one among many, sometimes more important than others and sometimes less so. These are political rather than legal considerations, but they have affected law. In legal doctrines proper, both theories hare been upheld for the same purpose, and each for opposed ends. Corporate groups less than the state have had real personality ascribed to them, both in order to make them more amenable to liability, as in the case of trade-unions, and to exalt their dignity and vital power, as against external control. Their personolity 
has been denied for like reasons; they have been pulverized into mere aggregates of separate persons in order to protect other laborers from them, to make more difficult their unified action in trade disputes, as in collective bargaining, and to enable union property to escape liability, the associated individuals in their severalty having no property to levy upon. The group personality theory has been asserted both as a check upon what was regarded as anarchic and dissolving individualism, to set up something more abiding and worthful than a single human being, and to increase the power and dignity of the single being as over against the state. Even the doctrine that true personality resides only in the "natural" person has been worked in opposed directions. It was first used to give church or state a short and direct road of approach which would lessen the power of the singular being over against the collective being, while lately, through being affected by "natural" in the sense of natural rights, it has been employed to exalt private, at the expense of public, interests.

Unfortunately, the human mind tends toward fusion rather than discrimination, and the result is confusion. I quote at length from a recent writer: "A position intermediate between the biological and the psychological theories of the state is held by Gierke and Maitland, whose point of view is shared by such writers as Figgis, Laski and Duguit. The founder of this position was the German jurist, Johannes Althusius. . . . His theory of the state as a hierarchy of constituent groups was broadened out by his modern interpreter, Otto Gierke, in his Genossenschaftslehre, which was sponsored and clarified by the eminent English historian and jurist, F. W. Maitland. Briefly, the doctrine is that the state is not a collection of individuals but an aggregation of groups. These groups, in turn, are not merely a plural number of individuals, but an organization of individuals designed to achieve a definite purpose. As purposive groups they are psychic organisms, possessing not a fictitious but a real psychic personality. . . . The exponents of this doctrine of the reality and significance of the group range in their interpretation of the place and significance of the state all the way from the position of such writers as Ernest Barker, who supports an Aristotelian-Hegelian adulation of the state, to the extreme pluralists and the Syndicalists, who would eliminate the state altogether." 18

The author is writing from the political point of view, not the legal; and the last sentence makes allowance for divergence of views as to the place of the state. But the passage gives the impression of a single school, coherent in its premises if not in its political conclusions. Analysis of the account, therefore, is not just for the sake of convicting Mr. Barnes of error, but for

18 Barnes, Sociology and Political Theory (1924) 29-30. 
the sake of revealing the fate of any conception that, by ignoring context and purpose, tries to introduce unity into a conception where the facts show utmost divergence. There is a forced assemblage of persons. Laski, like Althusius, has a political interest; but the political interest of the former was to afford a basis for popular government, while that of Laski was to moralize the idea of the state, to attack the idea of irresponsible sovereignty, and, under the influence of the pluralistic philosophy of James, to utilize the importance of the group, assumed currently in the sociology of the period, to dwell upon the vitality and autonomy of group interests. Althusius, on the other hand, in the latter, in contracting themselves into the state, lost their autonomous standing with respect to it. ${ }^{29}$ The interest of Figgis in grouppersonality appears to be wholly conditioned upon his desire to preserve the autonomy of ecclesiastic organizations, especially that of the Church of England.:

${ }^{19}$ His (Laski's) article on Peisonality of Associations closes with a seetion introduced by these words: "If what we have here been urging is true, it reacts most forcibly upon our theory of the state. Thus far, for the most part, we have sought its unification. We have made it intolerant of associations within itself-associations that to Hobbes will appear comparable only to 'worms within the entrails of a natural man'. As a resuit we have made our state absorptive in a mystic, Hegelian fashion. It is all-sovereign and unchallengeable. . . . But sovereign your state no longer is if the groups within itself are thus self-governing. Nor can we doubt this polyarchism. Everywhere we find groups within the stats which challenge its supremacy. They are, it may be, in relations with the state, a part of it; but one with it they are not. They refuse the reduction to unity. We find the state, in James' phrase, to be distributive and not collective". Foundations of Sovercignty (1921) 168-169, originally printed in (1916) 29 Harv. L. REv. 404. The statements about the relation of groups and the state may be true, historically, sociologically and ethically. But they are an argument for the rolitional personality of these acsociations only on the theory that the state is also a personal unified will. It was not the Hobbessian theory, or any similar theory, which produced the magnification of the state; the centralizing tendencies of the new national state produced the theory. Similarly, the rising social, cconomic and political importance of associations is producing, in analogy with the concept of the older theory of the state, a theory of thcir metaphysical personality. One can get the same practical results with a theory lilie Duguit's, which denies not only the personality of both state and groups but also of the natural individual, as a substratum of rights-duties. "Publie law has become objective just as private law is no longer based on individual right or the autonomy of a private will, but upon the idea of a social function imposed on every person". Duguit, Law in the IIodern State (1919, translated by Laski) 49. Again, "In private law the autonomy of the human will is in process of disappearance; the individual will is powerless by itself to create a legal situation." Duguit, supra at $\mathbf{2 4 3}$.

$20 \mathrm{It}$ is interesting to note, as an instance of the particular and "pragmatic" origin of much of the English theorizing, the lange part played by the case of the Free Church of Scotland v. Orcrtoun [1901] A. C. 515, and of the trades unions decisions in the Taff V'ale case [1901] A. C. 426 and the Osborme case [1910] A. C. 87. For the former see Vinagradofi, 
Gierke's interest was primarily legal; he wrote at a time when no German writer of influence would have thought of depreciating the personality of the state; that was taken for granted. The practical issue was found in the quarrel between Romanists and Germanists; Savigny the great Romanist had come out for the persona ficta theory of corporate bodies. Gierke wrote as a Germanist to oppose him, and the quarrel found its practical bearing in the fact that the German Civil Code was being drawn. Maitland writes primarily as a historian of legal institutions, although his political interest is sufficient to make him remark that "the State's possession of a real will is insecure if no other groups may have wills of their own". ${ }^{21}$ While he leans toward the real personality theory, it is safe to say that he is much more interested in a comparison of German and English theories and practices than he is in any theory; and any one interested in denying the theory can find much material in the rich store Maitland provides. ${ }^{22}$ Duguit writes as a lawyer, and his political interest is in making the "state", all officers of government-legally liable. He denies will and personality to both the state and all other groups. "Nor is it [fault] imputable to the collectivity since the latter outside the imagination of lawyers has no personal existence". ${ }^{23}$ As for Ernest Barker, he is indeed strong for the personality of the state, but his purpose is identical with that of Duguit, who denies precisely what Barker asserts: "What is needed is, in the first place, the conception of the State or the Public as a legally responsible person; and, in the second place, the application to this person of the idea of agency in such sort that it shall admit responsibility for the acts of its servants done in its service." 24 Specifically he wants some kind of administrative and law courts, in which the state through its agents,

Juridical Persons (1924) 24 CoL. L. REv. 594, at 597-599. Laski, op. cit. supra note 19, at 165-166 has a few comments on the latter two cases. There is a strange logic implied in the reasonings of the "real group personality" school that, since unwise decisions have been reached in a number of cases under cover of the "fictitious person" theory, the "real personality" view must be necessary to reach a correct decision. There is surely more than one omitted alternative possibility.

21 Gierke (with preface by Maitland), op. cit. supra note 3, at xlii.

22 Thus his whole discussion of trusts shows how much has been accom* plished, avoiding some of the attending difficulties of German law, "without troubling the state to concede or deny the mysterious boon of personality." 3 Collected Papers 283. His remark that "it's often struck me that morally there is most personality where legally there is least" certainly cuts both ways. The fact that the family, which is the most intimate emotional and volitional unity, is not a jural personality, has given the adherents of the real personality theory much difficulty.

23 Duguit, Law in the Modern State (1919) 205.

24 Barker, The 'Rule of Law' (May, 1914) The PoLitical Quarterir, 117, at 123. For a full discussion of this matter see Borchard, Government Liability in Tort (1924) 34 YALE LAW JOURNAL, 1, 129, 229. 
can be rendered liable, although not administrative law of the French type. Finally, the reference to "psychic organisms" is either gratuitous or highly misleading. It is not psychic personality which these writers-as far as they do hold to the personality of the state-are concerned with, but a moral personality, that is unity of organized action involving "will". The idea of psychic personality is read in from writers on social psychology and sociology.

I do not make this examination for the sake of indieating that MIr. Barnes sins above others. As already said, the collection of commissions and omissions is the sort of thing which is bound to happen when one assumes that there is in existence some single and coherent theory of personality and will, singular or associated. Nothing accurate or intelligible can be said except by specifying the interest and purpose of a witer, and his historical context of problems and issues. Thus we end where we began: with the statement that the entire discussion of personality, whether of single or corporate personality, is needlessly encumbered with a mass of traditional doctrines and remnants of old issues. Almost every English writer, beginning with Maitland, who has written in behalf of the doctrine of the "real personality" of corporate bodies, has felt obliged to quote the following from Dicey: "When a body of twenty or two thousand or two hundred thousand men bind themselves together to act in a particular way for some common purpose, they create a body which by no fiction of law but by the very nature of things, differs from the individuals of whom it is composed." Assuredly; but why should such a fact be thought to have any bearing at all upon the problem of personality? Only because the doctrine of "fictitious" personality has been employed, under the influence of the "individualistic" philosophy already referred to, in order to deny that there is any social reality at all back of or in corporate action. Hence the assertion of the simple fact that there is some social reality involved got bound up with the notion of a real, as distinct from fictitious personality. The example, it seems to me, is sufficiently striking to enforce the value of eliminating the idea of personality until the concrete facts and relations involved have been faced and stated on their own account: retaining the word will then do no great harm. 